\title{
Research and Analysis on the Current Situation of Land Transfer
}

\begin{abstract}
Liu Ziyi*
New Channel School

*Corresponding author. Email: 2823794674@qq.com

ABSTRACT

Since the founding of The People's Republic of China, land transfer has been an important part of China's economic development, land reform, farmers' rights and interests, the construction of a well-off society throughout the year, and poverty alleviation. Since the 19th National Congress of the COMMUNIST Party of China (CPC), land transfer among the three powers has become the top priority in the transformation of rural economic development. Why is land circulation important, its reform experience, how is the current situation, and how will it develop in the future, this paper combined with the problems existing in China's rural land circulation system in recent years through analysis and put forward some countermeasures. The conclusion of this article is that we need to attach great importance to and improve the education and awareness of farmers, and constantly improve the government's internal supervision system.
\end{abstract}

Keywords: Land circulation, countermeasures, people's rights and interests, economic development

\section{INTRODUCTION}

Land transfer refers to the transfer of land management rights (use rights) by farmers with land contract management rights to other farmers or economic organizations, that is, to retain the contract rights and transfer the use rights. After the management rights are transferred to the period, they still belong to the farmers during the land contract period. Land transfer is conducive to preventing land abandonment; conducive to promoting agricultural industrialization and large-scale production; for farmers, it is conducive to income increase. Most farmers have land, but the area is small. In recent years, many farmers have chosen to transfer the land. However, because farmers have little knowledge of land transfer, various problems have arisen. This paper analyzes the generation and development of land circulation, discovers the existing problems, and proposes some solutions to the problems faced by land circulation, so as to guide related practical activities in the future.

\section{LAND CIRCULATION}

China's land circulation after 1950's land reform, the abolition of the former feudal land ownership burst into a new bud. However, due to the national consciousness and economic constraints at that time, there was not enough economic market to support the land transfer in the social environment at that time, which led to the fact that the land transfer in China did not show a qualitative leap in the previous decades.

\section{CURRENT LAND CIRCULATION}

Under the policy support of the Opinions of the CPC Central Committee and the State Council on Implementing the Rural Revitalization Strategy, which was released by the CPC Central Committee in 2018, China's land circulation has shown an accelerated trend and developed to a new height. To a certain extent, it has effectively helped China achieve the goal of a well-off society for all and improved the living conditions of Chinese farmers.

\subsection{Land Transfer}

Land circulation refers to the circulation of land use right. The meaning of land circulation is that farmers with land contracting right transfer their land management right to other farmers or economic organizations, that is, retain the right to contract and transfer the right to use.

In 2004, the State Council promulgated the "Absolute Law on The Strict Management of Land for 
Deepening Reform", which stipulated that the right to use construction land owned by peasant collectives could be transferred according to law [1].In 2014, the General Office of the CPC Central Committee and the State Council issued the Opinions on Guiding the Orderly Transfer of Rural Land Management Rights to Develop Moderate Scale Agricultural Operations, which required that land transfer and moderate scale agricultural Operations be vigorously developed and the contracted management rights be confirmed within five years.

\subsection{Advantages and Effects of Land Transfer}

At present, land circulation shows the trend of "from coastal to land" and the popularization is increasing. This progress has effectively improved the utilization rate of Thesis on social Entrepreneurship

\subsubsection{Resource allocation}

Promote the development of rural industrialization. The high development of rural secondary and tertiary industries has attracted a large number of labor forces. Under the current situation of China, 800 million out of 1.4 billion people are farmers. It can be concluded that how to find a breakthrough in the bottleneck of agricultural development is crucial. Based on the results of China's current regional land transfer policy development, land transfer has effectively improved the living conditions of farmers, driven the development of planting and breeding industry, and successfully solved the problem of land fragmentation since the founding of China [2].At the same time, land circulation has also improved the allocation of resources in China, accelerated the intensification and large-scale improvement of rural land in China, and broken through the bottleneck of small-scale family management. For example, the land scattered in each household can be traded in the form of market, so that some large rural leading enterprises with capital, technology, experience and management can implement intensive management to achieve mass and large-scale economic benefits. To achieve a reasonable distribution of rural manpower, financial resources, materials, and improve rural income efficiency.

\subsubsection{Rural urbanization land}

Circulation not only promotes the reasonable flow of capital, technology and labor force between urban and rural areas, but also solves the problem of land utilization rate in China, showing a trend that contracted land can achieve the highest utilization rate, high output and high quality. For example, the current problem of surplus rural labor force is very prominent, and some farmers cannot correctly get rid of their life status by their own strength due to their awareness and education problems. Therefore, the importance of establishing land use right market is highlighted again. On the one hand, it can help those land farmers who have no experience and technology and are unable or unwilling to operate to liberate themselves from their life plight. On the other hand, it also accelerates the progress of rural urbanization in China and increases agricultural income constantly.

\subsection{Deficiencies of current land circulation}

\subsubsection{Farmers' consciousness}

According to my actual investigation in Sunhe Guai Village and Qiantun Village, the problems still existing in land circulation in China are characterized by weak personal cognition and consciousness of farmers, as well as unstable negative attitudes and positions. The reason for these phenomena is that China's land transfer is still in the stage of exploration and perfection. According to the data, $30 \%$ of the villagers were persuaded or forced to join the land transfer by the local government, $80 \%$ of the villagers did not even know the land, and more than $90 \%$ of the villagers did not know what benefits they could get. This leads to a phenomenon most to land circulation of the villagers didn't actually is really involved, they were encouraged to join, join after moment with an uneasy heart, because they feel they can't do anything, can't do anything, negative attitude, this is the big fear of land circulation, to implement land circulation is the true sense, must ensure the every people actively involved in the project [3].For example, the widespread fear of "chaos" among farmers leads to their misunderstanding of this policy and project due to their low level of education and lack of awareness, and they dare not or even are not allowed to transfer the land.

\subsubsection{Policies}

Some governments do not do anything, which not only does not play the leading role, but has been helping. This phenomenon embodied in some village cadres, their ignorance, not method, not use to safeguard the interests of the villagers, just that there are even some cadres, to public funds with their different channels into their own, which makes the villagers didn't believe policy, is not willing to cooperate, moreover directly refuse to cooperate, this kind of phenomenon has become the land circulation in our country on the way of development.

\subsubsection{Relevant laws}

There are currently no relevant laws to support land transfer projects

Spontaneity, blindness and randomness are the current situation of land circulation in China, which leads to many loopholes. For example, the content of 
land circulation is incomplete, the content popularization is low, and the price and income of land circulation are unstable, which cannot improve the economic system of China in a real sense.

\subsubsection{Circulation mechanism}

in the middle of the land circulation mechanism is not perfect, at present, most of the region and failed to form a sound, specification of land circulation market economy lack of related agencies, and no experience, causes our country land circulation policy frequently blocked, such as information is not complete, information communication is not smooth, not smart, or even wrong information, the serious influence factors of the success of the project land economy, without actually improve labor, resources, and the reasonable distribution of the material flow, and optimization.

\section{COUNTERMEASURES FOR FUTURE DEVELOPMENT OF LAND CIRCULATION}

\subsection{Pay High Attention to and Improve Farmers' Education and Awareness}

At the present stage, the education level of most villagers is still backward, leading to the phenomenon of weak consciousness and low enthusiasm, and most of them refuse to accept new ideas and ideas and still remain in the self-sufficient small-scale peasant economy system. Therefore, it is very important to strengthen villagers' awareness and recognition of land circulation.

In surveys conducted in The villages of Sun He Guai and Qiantun, it is generally found that villagers use their mobile phones and some apps on them very frequently, such as Douyin and Kuaishou. In order to strengthen the awareness of villagers, the first step we need to do is to vigorously promote China's land transfer project, subtly improve the popularity of land transfer among villagers, so that villagers are more willing to cooperate with the government work more actively and accelerate the development of land transfer [4].

\subsection{Continuously Improve the Supervision System within the Government}

Under the premise of villagers' enthusiasm, the leading role played by the government is of course important. The government should constantly improve social security and its own services, so that villagers can identify with, trust and cooperate with the government [5].

According to the previous investigation and data show that, although our government cannot achieve perfection, but should effectively strengthen the attention to China's land transfer project, attention and support strength. At the same time, relatively reasonable policies will be introduced to create a better platform and a more convenient and convenient way for land circulation to promote the development of land circulation in the future. Moreover, the enhancement of government support should not only reflect the improvement of existing policies and systems, but also reflect the support of funds, truly understand the living conditions and economic conditions of each family, and provide relatively reasonable funds to ensure the smooth progress of land transfer.

The foundation of all these, which is the most important thing, is to strengthen the improvement of the supervision system. The main object of attention is the village cadres[6]. When selecting village cadres, careful consideration should be given to selecting talents that can be appointed to take charge of the project and the village. Moreover, some cadres do not seek their own positions and do not consider the interests of the people. For their own selfish interests, they are ignorant of the law and violate the law, and they are lazy and unscrupulous in governing the land. Therefore, it is extremely important to strengthen the supervision system of our country.

\section{CONCLUSION}

China has been known as an agricultural country since ancient times, and land is the foundation of agriculture. Therefore, China's economic development cannot be separated from the dependence and utilization of land, so it is very important to study and improve the land circulation in China. Facts have proved that land circulation has effectively improved China's agricultural economic system and agricultural development, promoted the development of Poverty alleviation policies in China, ensured the long-term and stable development of agriculture, and further promoted the use and distribution of land, which is a feasible way.

\section{ACKNOWLEDGMENT}

First of all, I would like to thank the professor for guiding me to finish this paper, as well as my paper adviser and teaching assistant for helping me to improve and revise this paper repeatedly. Secondly, I would like to thank the students in our group. With their materials and ideas, my paper is more substantial, more accurate and more convincing.

\section{REFERENCES}

[1] Liu Zhihong. Current situation, problems and Countermeasures of rural land circulation [J]. Agricultural engineering technology, 2020,40 (05): $8+10$ 
[2] Sun Chengchao. Current situation and Countermeasures of surplus labor transfer under land transfer $[\mathrm{J}]$. Rural economy and technology, 2019,30 (18): 180-1813.

[3] Wang Wenbin. Research on the difficulties and solutions of Rural Talent Gathering [J]. Reform and strategy, 2016,32 (04): 42-46

[4] Wang Hongying. Analysis on the current situation of the transfer of rural land contractual management right and countermeasures [J]. Shanxi Agricultural Economics, 2017 (01): 4-5
[5] Yang Xingping, Fu Zhiyu. Problems and Countermeasures of rural land circulation: a case study of Sichuan Province [J]. China development, 2014,14 (02): 51-57

[6] Deng Lei, Zhu Chaozhi. The dilemma of rural land transfer in Fujian Mountainous Areas and Its Countermeasures: a case study of Jiangkou Village in Nanping City $[\mathrm{J}]$. Agricultural exploration in Taiwan, 2015 (04): 48-51 